Review

\title{
Healing Effects of Photobiomodulation on Diabetic Wounds
}

\author{
Nicolette Houreld \\ Laser Research Centre, Faculty of Health Sciences, University of Johannesburg, Doornfontein, \\ Johannesburg 2094, South Africa; nhoureld@uj.ac.za; Tel.: +27-11-559-6833
}

Received: 30 September 2019; Accepted: 19 November 2019; Published: 26 November 2019

\begin{abstract}
Diabetic patients frequently develop chronic ulcers of the lower extremities, which are a frequent cause for hospitalization and amputation, placing strain on patients, their families, and healthcare systems. Present therapies remain a challenge, with high recurrence rates. Photobiomodulation (PBM), which is the non-invasive application of light at specific wavelengths, has been shown to speed up healing of chronic wounds, including diabetic foot ulcers (DFUs). PBM produces photophysical and photochemical changes within cells without eliciting thermal damage. It has been shown to promote tissue regeneration and speed up wound repair by reducing inflammation and oxidative stress, accelerating cell migration and proliferation, and promoting extracellular matrix production and release of essential growth factors. The shortage of rigorous, well-designed clinical trials makes it challenging to assess the scientific impact of PBM on DFUs, and lack of understanding of the underlying mechanisms also hinders the conventional use of this therapy. This review gives a glimpse into diabetic wound healing and PBM, and the effects of PBM on diabetic wound healing.
\end{abstract}

Keywords: photobiomodulation; laser therapy; diabetes mellitus; diabetes; wound healing; chronic ulcers

\section{Introduction}

The number of diabetic patients worldwide is on the rise, with a 2017 estimated global prevalence of $8.8 \%$ aged between 20 and 79 years ( 424.9 million), which is expected to increase to $9.9 \%$ (628.6 million) by the year 2045 [1]. Approximately $4.0(3.2-5.0)$ million people aged between 20 and 79 years are estimated to have died from diabetes mellitus (DM) in 2017; that is equivalent to one death every eight seconds [1]. Diabetes in all forms imposes an excessively high human, social, and economic cost on all income level countries. In 2017, the total healthcare expenditure by people with DM stood at US dollars(USD) 727 billion for those aged 20-79 [1].

Foot complications are among the most serious, debilitating, and costly complications of DM. Patients with DM commonly develop chronic, slow-to-heal ulcers that affect the lower extremities. These chronic wounds are a common and frequent cause for hospitalization and amputation, leading not only to incapacity and decreased quality of life, but also affecting psychological wellbeing, contributing to depression and placing financial strain on individuals, families, and healthcare systems. In 2007, one-third of diabetes costs were estimated to be linked to diabetic foot ulcers (DFUs), and currently patients experience health expenditure five times higher than those without foot ulcers [1]. DFUs are the most frequent cause of non-traumatic lower limb amputation [2], resulting in not only limb loss but also contributing to a 3-year mortality rate of 75.9\% [3]. The International Diabetes Federation [1] estimates that a lower limb or part thereof is lost to amputation somewhere in the world as a consequence of diabetes every $30 \mathrm{~s}$. It has been approximated that diabetic patients have a $25 \%$ lifetime risk of developing a foot ulcer, and are 100 times more likely to suffer from lower extremity amputation than 
euglycemic patients [4]. Once an amputation has occurred, half of patients will develop an ulcer in the contralateral limb within 5 years [5], placing a further burden on patients. This personal and financial burden is expected to increase along with the anticipated increase in the prevalence of DM.

Current treatments for DFUs rely on patient education, prevention, early diagnosis, and comprehensive management [2]. Current therapies remain a challenge, with high recurrence rates. Photobiomodulation (PBM) has been shown to be beneficial in the treatment of a variety of medical conditions and pathologies, including chronic wounds and DFUs. PBM is defined as a mechanism by which nonionizing optical radiation in the visible and near-infrared (NIR) spectral range is absorbed by endogenous chromophores to elicit photophysical and photochemical events at various biological scales without eliciting thermal damage. Photobiomodulation therapy (PBMT) is defined as a photon therapy based on the principles of PBM [6]. Due to the need for the development of a more rapid, productive, cost-effective, and appropriate therapy to facilitate healing of chronic wounds, particularly DFUs, the use and further investigation of PBM is warranted.

\section{Diabetic Wound Healing}

Chronic wounds rarely occur in healthy individuals and frequently occur as a comorbidity with other diseases and conditions, such as DM, obesity, and spinal cord injury. A chronic wound is one which has failed to proceed through an orderly and timely reparative process. These wounds often become stuck in the inflammatory phase of healing and typically do not heal within three months. Diabetic ulcers of the lower extremities occur as a common complication of DM and involves a multifactorial pathogenesis including peripheral neuropathy and peripheral vascular disease, repetitive external trauma to the feet, and infection [7]. Most infected DFUs require some surgical intervention, ranging from minor to major interventions, including debridement and amputation, respectively. Infected DFUs are a major cause of lengthy hospital admission and contribute to more than a million amputations per year [8], with a 50\% 5-year mortality rate amongst diabetic amputees [9].

Wound healing in diabetes is impaired by extrinsic and intrinsic factors. Extrinsic factors include repeated trauma or mechanical stress to the foot. Intrinsic factors play a major role in the development of DFUs. Hyperglycemia leads to the formation of advanced glycation end-products (AGEs) which prompt the production of inflammatory cytokines. There is also a decrease in collagen production and other essential extracellular matrix (ECM) proteins, and an increase in their destruction by matrix metalloproteinases (MMPs). There are also alterations in cellular morphology, abnormal differentiation of keratinocytes and fibroblasts, decreased cellular proliferation, altered immune function, and altered bioavailability of cytokines and growth factors [10]. There are also conditions of hypoxia, which impact negatively on wound healing.

Treatment of DFUs is centered on eliminating infection, the use of dressings to maintain a moist wound bed and to absorb exudate, offloading high pressure from the wound bed, and debridement to accelerate endogenous healing and facilitate the effectiveness of topically applied substances [11]. With the advancement of technology, new treatments for diabetic ulcers have been developed and include the incorporation of nanoparticles and growth factors into wound dressings, tissue-engineered human skin equivalents, stem cell therapy, vacuum-assisted closure (VAC) devices, hyperbaric oxygen therapy (HBOT), and gene therapy. Advances in the area of photonics and biophotonics has led to the efficacious use of light in the treatment of diabetic wounds.

\section{Photobiomodulation (PBM)}

The use of light as a therapy dates back to ancient civilizations, with ancient Egyptians and Indians making use of sunlight (heliotherapy) for healing and promoting health. Professor Endre Mester reported the earliest application of PBM in 1967. He described how irradiation accelerated hair growth on the back of shaven mice [12]. This piqued his interest, and he went on to show how PBM could stimulate wound healing in mice [13] and in human patients [14,15]. The use of light as a treatment has 
subsequently evolved and is used to reduce inflammation and edema, to treat neurological disorders and pain, and to promote healing of various tissue types.

PBM involves the use of nonionizing forms of light from sources including lasers, light-emitting diodes (LEDs), and broadband light in the visible and near-infrared (NIR) spectra to cause physiological changes and therapeutic benefits. It is a non-invasive phototherapy that can be used alone or in combination with other wound treatments. PBM produces photophysical and photochemical changes within cells without eliciting thermal damage. Despite the fact that PBM is applied to treat a wide variety of ailments, it remains underutilized and controversial. This is mainly due to the poor understanding of the underlying cellular and molecular mechanisms, so its use is largely experimental. Another contributing factor is the fact that a large number of settings and parameters, such as wavelength (nanometers, $\mathrm{nm}$ ), fluence (joules per square centimeters, $\mathrm{J} / \mathrm{cm}^{2}$ ), power density (watts per square centimeters, $\mathrm{W} / \mathrm{cm}^{2}$ ), pulse structure (nanoseconds, $\mathrm{ns}$ ), and timing (seconds, $\mathrm{s}$ ) of the applied light must be carefully chosen for each treatment. A less than optimal choice of these parameters results in unsatisfactory findings or even a negative therapeutic outcome [16]. There is almost a complete lack of reports of side effects or adverse events associated with PBM [16], something which counts largely in its favor.

Light that falls within the so called "optical window" at red and NIR wavelengths (600 to $1070 \mathrm{~nm}$ ) are typically used for PBM [16]. The lower wavelengths in the red spectrum (600 to $700 \mathrm{~nm})$ do not penetrate into tissue as deeply and are used to treat superficial tissue, while longer wavelengths (780 to $950 \mathrm{~nm}$ ) penetrate much deeper and are used to treat deeper-seated tissues. The application of light in the blue/violet spectrum has been shown to suppress pathogenic bacterial growth. The power of light used typically lies in the range of 1 to $1000 \mathrm{~mW}$ and depends on the application. The dose (or fluence), which is a function of the combination of irradiance (medicine) and time (dose), is also very important, and also varies depending on the application [16].

\subsection{Mechanisms of PBM}

The precise mechanisms of action of PBM are not fully known and understood, however a broad range of effects at the molecular, cellular, and tissular levels have been observed. What is known is that PBM appears to have a profound effect on the cellular mitochondria where the photons are absorbed by various components of the respiratory chain, primarily complex IV or cytochrome c oxidase (Cox), which transfers electrons from cytochrome $\mathrm{c}$ to molecular oxygen [17-19]. The photoreactivity of Cox is due to its four metal centers; two heme moieties (heme a and heme a3) and two redox-active copper sites (CuA and $\mathrm{CuB})[20]$.

Karu and colleagues [21] revealed that the redox state of Cox is influenced by red light, and is dependent on the initial redox state at the time of irradiation. It was also shown that irradiation intensified the transfer of electrons in Cox, resulting in accelerated oxidative phosphorylation [20]. An increase in other electron transfer complexes has also been observed. Yu and co-workers [22] found an increase in enzyme activity of complex I, III, and IV in irradiated isolated mitochondria $(660 \mathrm{~nm}$; $10 \mathrm{~mW} / \mathrm{cm}^{2} ; 0.6,1.2,2.4$, and $4.8 \mathrm{~J} / \mathrm{cm}^{2}$ ). Masha et al. [23] found up-regulation of genes coding for complex I, IV, and V following irradiation at $660 \mathrm{~nm}\left(11 \mathrm{~mW} / \mathrm{cm}^{2}, 5 \mathrm{~J} / \mathrm{cm}^{2}\right)$. The effect on mitochondria results in increased adenosine triphosphate (ATP) synthesis [19,24], proton electrochemical potential [24,25], and oxygen consumption, as well Nicotinamide adenine dinucleotide (NADH) synthesis [26]. The increase in ATP has been found to peak immediately in irradiated mouse embryonic fibroblasts $\left(810 \mathrm{~nm} ; 0.3,3\right.$, and $\left.30 \mathrm{~J} / \mathrm{cm}^{2}\right)$ and decline to baseline levels over $6 \mathrm{~h}$ [27]. Increased levels of ATP following PBM have also been found under hypoxic conditions [28-30], which normally results in decreased ATP synthesis [29].

There is also modulation of intracellular reactive oxygen species (ROS), which are involved in cell signaling pathways and gene transcription. Under normal physiological conditions, ROS are produced during the synthesis of ATP, and since PBM boosts oxygen metabolism, it also acts to increase ROS production [16]. PBM also displaces nitric oxide (NO) from Cox. NO inhibits mitochondrial respiration 
by binding to the heme iron:copper binuclear center $(\mathrm{a} 3 / \mathrm{CuB})$ of Cox, thus displacing oxygen [31,32]. This photodissociation allows for the influx of oxygen and resumption of respiration $[31,33]$. It has also been hypothesized that PBM may also dissociate NO from intracellular stores, such as nitrosylated hemoglobin and myoglobin, leading to vasodilation [34]. Laser irradiation $\left(830 \mathrm{~nm}, 4.4 \mathrm{~mW} / \mathrm{cm}^{2}\right.$, $5 \mathrm{~J} / \mathrm{cm}^{2}$ ) of human skin fibroblast cells resulted in an increase in ROS and NO 15 min post-irradiation in what would appear to be a direct photochemical effect [35]. Chen et al. [27] demonstrated an increase in mitochondrial ROS fluorescence in irradiated $\left(810 \mathrm{~nm} ; 1-30 \mathrm{~mW} / \mathrm{cm}^{2} ; 0.3,3\right.$, and $\left.30 \mathrm{~J} / \mathrm{cm}^{2}\right)$ murine embryonic fibroblasts. Pal et al. [36] found that the generation of ROS in irradiated $(632.8 \mathrm{~nm}, 0.5$ to $16 \mathrm{~J} / \mathrm{cm}^{2}, 0.64$ to $1.16 \mathrm{~mW} / \mathrm{cm}^{2}$ for whole cell culture irradiation; and $330 \mathrm{~mW} / \mathrm{cm}^{2}$ to $20 \mathrm{~W} / \mathrm{cm}^{2}$ for single cell irradiation) human skin fibroblasts was dependent on laser fluence and not on laser intensity. Zhang et al. [30] showed that PBM increased intracellular NO in irradiated cardiac cells $(670 \mathrm{~nm}$, $25 \mathrm{~mW} / \mathrm{cm}^{2}, 7.5 \mathrm{~J} / \mathrm{cm}^{2}$ ), an effect which was no longer evident when NO scavengers were added and partially impeded by nitric oxide synthase (NOS) inhibitors. Zhang et al. [30] came to the conclusion that the increase in NO was due to NOS and a second unidentified source, possibly photodissociation from Cox.

When it comes to irradiation and destruction of bacteria with blue/violet light, the mechanism of action centers around the production of high amounts of ROS. Irradiated light is absorbed by photoacceptors within the bacterium such as porphyrins and flavins [37]. These phorphyrins absorb the photon energy, become excited, and jump to the triplet state. They then release the extra energy and pass it onto molecular oxygen creating ROS, which interact with numerous macromolecules within the cell causing cellular damage and leading to cell death [38].

\subsection{Cellular Effects of PBM}

PBM has been shown to affect cell functions, such as viability, proliferation, migration, and metabolism, in a variety of cell types, including fibroblasts, mast cells, osteoblasts, Schwann cells, stem cells, keratinocytes, and smooth muscle cells. It has been shown to promote tissue regeneration and speed up wound repair by reducing inflammation and stimulating cell migration and proliferation, ECM production, and release of essential growth factors, and increasing the mean breaking strength of the wound.

Amaroli and colleagues [39] evaluated various cellular responses in human endothelial cells (HECV) irradiated with an $808 \mathrm{~nm}$ diode laser $\left(1 \mathrm{~W} / \mathrm{cm}^{2}, 60 \mathrm{~J} / \mathrm{cm}^{2}\right.$; or $\left.0.95 \mathrm{~W} / \mathrm{cm}^{2}, 57 \mathrm{~J} / \mathrm{cm}^{2}\right)$. Cellular viability, free radical-induced oxidative stress, nuclear factor kappa B (NF- $\mathrm{BB}$ ) activation, NO release, mitochondrial respiration, and wound healing repair were measured. Irradiated cells demonstrated increased proliferation and migration coupled with a moderate increase in ROS production without a significant increase in oxidative stress and oxidative stress-activated processes. PBM stimulated mitochondrial oxygen consumption and ATP production. There was no effect on cellular viability, however, PBM led to an increased wound healing rate. Their results demonstrated that NIR light led to a shift from anaerobic to aerobic metabolism. Assis et al. [40] also showed PBM was effective in modulating oxidative stress and reducing inflammation in injured muscle. Irradiation $(808 \mathrm{~nm}$, $3.8 \mathrm{~mW} / \mathrm{cm}^{2}$, total energy $1.4 \mathrm{~J}$ ) not only lessened oxidative and nitrative stress, but also reduced lipid peroxidation, nitrotyrosine formation, NO production, and the inflammatory response (NF- $\kappa \mathrm{B}, \mathrm{COX}-2$, TNF- $\alpha$ and interleukin(IL)-1 $\beta$ ) and amplified superoxide dismutase (SOD) gene expression. Otterço and colleagues [41] irradiated wounded rats with a wavelength of $670 \mathrm{~nm}\left(30 \mathrm{~mW}, 14.28 \mathrm{~J} / \mathrm{cm}^{2}\right)$ for 15 consecutive days. Histopathological analysis revealed a lower inflammatory infiltrate, as well as increased collagen. There was an increase in vascular endothelial growth factor (VEGF) and a decrease in tumor necrosis factor-alpha (TNF- $\alpha$ ).

Growth factors have an important role during wound repair and are involved in regulating cell growth, division, differentiation, and migration, and are also concerned with various signaling pathways. Numerous studies have shown the beneficial effect of PBM on the increased production of various growth factors essential to wound healing. Damante and colleagues [42] showed that 
irradiation of human gingival fibroblasts by an infrared laser $\left(780 \mathrm{~nm} ; 1 \mathrm{~W} / \mathrm{cm}^{2} ; 3\right.$ and $\left.5 \mathrm{~J} / \mathrm{cm}^{2}\right)$ led to the increased production and secretion of basic fibroblast growth factor (bFGF). Jere et al. [43] demonstrated an increase in cell migration rate, proliferation, and viability, as well as an increased release of epidermal growth factor (EGF) in wounded fibroblast cells, which lead to activation of the JAK/STAT signaling pathway.

The effect of PBM in aged animals has also been shown to be effective. Fiorio et al. [44] investigated PBMT $\left(660 \mathrm{~nm}, 1.07 \mathrm{~W} / \mathrm{cm}^{2}, 72 \mathrm{~J} / \mathrm{cm}^{2}\right)$ in cutaneous wound healing in aged rats (500 days). The study demonstrated that PBM is effective in the modulation of inflammatory mediators (IL-6, CINC-1, and VEGF) and matrix metalloproteinases and their inhibitors (MMP-3, MMP-9, and TIMP-2). There was also increased collagen production during different phases of tissue regeneration.

\subsection{Effects of PBM Using Blue Light on Bacterial Growth and Fibroblasts}

PBM has been shown to eradicate bacteria within the blue spectrum of light. Lipovsky and colleagues [37] irradiated Staphylococcus aureus (S. aureus) and Escherichia coli (E. coli) with a halogen lamp with filters for irradiation in the blue $(400-500 \mathrm{~nm})$ and red $(500-800 \mathrm{~nm})$ spectra, or with blue LEDs (415 and $455 \mathrm{~nm} ; 100 \mathrm{~mW} / \mathrm{cm}^{2}$; for 30, 60, and $120 \mathrm{~J} / \mathrm{cm}^{2}$ ). There was more ROS production in bacterial cells exposed to blue light $(400-500 \mathrm{~nm}$ ) than those exposed to red light (500-800 nm). When irradiated with LEDs, $415 \mathrm{~nm}$ was found to be more valuable than a wavelength of $455 \mathrm{~nm}$, at higher fluences. A fluence of $30 \mathrm{~J} / \mathrm{cm}^{2}$ at $415 \mathrm{~nm}$ and a fluence of either 30 or $60 \mathrm{~J} / \mathrm{cm}^{2}$ at a wavelength of $455 \mathrm{~nm}$ resulted in an increase in proliferation of $S$. aureus.

Enwemeka and colleagues [45] showed that exposure of two strains of methicillin-resistant Staphylococcus aureus (MRSA) to blue light at a wavelength of $470 \mathrm{~nm}$ (output power of $150 \mathrm{~mW}$; irradiance of $30 \mathrm{~mW} / \mathrm{cm}^{2}$ ) was able to inhibit and kill the bacteria. Two strains of MRSA were used, IS-853 representing hospital-acquired methicillin-resistant S. aureus (HA-MRSA) and US-300 representing community-acquired S. aureus (CA-MRSA). Quantification of bacterial colonies and aggregate area of colonies $24 \mathrm{~h}$ post-irradiation showed that there was a dose-dependent reduction in both strains. A low fluence of $3 \mathrm{~J} / \mathrm{cm}^{2}$ produced $34.1 \%$ and $27.6 \%$ death for US-300 and IS- 853 strains, respectively, which increased to more than $48 \%$ and $67.3 \%$ at $7 \mathrm{~J} / \mathrm{cm}^{2}$, respectively. When a fluence of $11 \mathrm{~J} / \mathrm{cm}^{2}$ was provided, a reduction of $61.2 \%$ and $56.4 \%$ was observed, respectively. Over $80 \%$ bacterial death was noted in both strains when a fluence of $35 \mathrm{~J} / \mathrm{cm}^{2}$ was used, and there was an average death of $90.4 \%$ for both strains at a fluence of $55 \mathrm{~J} / \mathrm{cm}^{2}$, and $91.7 \%$ and $94.8 \%$ of the aggregate area was eradiated for US-300 and IS-853 strains, respectively. In a similar study, using the same LED light device $(470 \mathrm{~nm}$ wavelength; output power of $150 \mathrm{~mW}$; irradiance of $30 \mathrm{~mW} / \mathrm{cm}^{2}$ ) Bumah and colleagues [46] irradiated MRSA USA300 three times (with $30 \mathrm{~min}$ between exposures) to a fluence of $36 \mathrm{~J} / \mathrm{cm}^{2}$ (cumulative fluence of $108 \mathrm{~J} / \mathrm{cm}^{2}$ ) or four times (with $30 \mathrm{~min}$ between exposures) to a fluence of $65.5 \mathrm{~J} / \mathrm{cm}^{2}$ (cumulative fluence of $262 \mathrm{~J} / \mathrm{cm}^{2}$ ). MRSA treated with blue light at either exposure regimens did not express any bacterial growth. FTIR analysis showed that there were changes in DNA conformation and that irradiation of MRSA with $470 \mathrm{~nm}$ light induces A-DNA cleavage. Biener and colleagues [38] also showed that irradiation of MRSA USA300 to a diode laser with a wavelength of $405 \mathrm{~nm}$ (output power of $500 \mathrm{~mW}$; irradiance of $135 \mathrm{~mW} / \mathrm{cm}^{2}$ ) inhibited bacterial growth. Either bacterial cells were irradiated with a single dose, or a double dose with $30 \mathrm{~min}$ between doses; each dose was at a fluence of $121 \mathrm{~J} / \mathrm{cm}^{2}$. A double dose was found to be more efficient than a single irradiation. They also showed that there was depolarization of the cell membrane and that MRSA expressed demonstrable amounts of porphyrins, and its production was dependent on the cell cycle phase. It was suggested that blue light was able to target these porphyrins, and due to the production of ROS and attack thereof of the membrane, there was a decrease in the transmembrane potential, leading to cell death.

An important paper published by Masson-Meyers et al. [47] determined the effect of blue light on fibroblast cells. If blue light is to be used to treat infected wounds in vivo, the treatment protocol needs to have an inhibitory effect on the invading pathogen, while leaving the surrounding host cells intact. Cells were irradiated at a wavelength of $470 \mathrm{~nm}$ and different fluencies of 3, 55, 110, 
or $220 \mathrm{~J} / \mathrm{cm}^{2}$ (output power of $150 \mathrm{~mW}$; irradiance of $30 \mathrm{~mW} / \mathrm{cm}^{2}$ ). Four different assays were carried out to determine cellular viability $24 \mathrm{~h}$ post-irradiation. The MTT assay showed that irradiation with 55,110 and $220 \mathrm{~J} / \mathrm{cm}^{2}$ significantly impairs mitochondrial activities and decreases fibroblast viability. When cellular viability was determined by the neutral red assay as well as the Trypan blue assay, a significant decrease was observed following irradiation with 110 or $220 \mathrm{~J} / \mathrm{cm}^{2}$, indicating a disruption to the cell membrane integrity. Data attained from the live/dead fluorescence assay showed only slight, insignificant decreases in cell viability at all fluences tested. Overall, these results showed that there was a dose response in fibroblast cells in response to irradiation at $470 \mathrm{~nm}$, with fluences above 110 $\mathrm{J} / \mathrm{cm}^{2}$ becoming intolerable to cells. Opländer and colleagues [48] found that irradiation of fibroblasts at wavelengths of $410,420,453$, and $480 \mathrm{~nm}$ (irradiance of $50 \mathrm{~mW} / \mathrm{cm}^{2}$ ) at different fluences produced different results. Fibroblast numbers were significantly decreased when irradiated with $410 \mathrm{~nm}$ and $420 \mathrm{~nm}$ at 60 and $90 \mathrm{~J} / \mathrm{cm}^{2}$, whereas irradiation with $480 \mathrm{~nm}$ resulted in a significant increase at 30 and $60 \mathrm{~J} / \mathrm{cm}^{2}$. Irradiation with $453 \mathrm{~nm}$ produced no difference. Irradiations with $410 \mathrm{~nm}$ and $420 \mathrm{~nm}$ at a fluence of $10 \mathrm{~J} / \mathrm{cm}^{2}$ resulted in increased intracellular oxidative stress, while wavelengths of $435 \mathrm{~nm}$ and $480 \mathrm{~nm}$ produced no effect at the same fluence. This increase in oxidative stress was partly due to an increase in the production of singlet oxygen. Irradiations at $410 \mathrm{~nm}, 420 \mathrm{~nm}$, and $435 \mathrm{~nm}$ significantly reduced cellular proliferation when cells were irradiated daily with $10 \mathrm{~J} / \mathrm{cm}^{2}$ over 4 days, while irradiations with $480 \mathrm{~nm}$ had no effect on cellular proliferation.

Since PBM in the blue spectrum has been found to be lethal to bacterial growth, there is promise for this therapy to be used in the treatment of infected wounds, however, more detailed in vivo studies on infected wounds need to be conducted. An advantage of such a treatment is that there are no external drugs involved, and it is highly unlikely that bacteria will develop resistance to this kind of treatment. Caution should still prevail, however, as some wavelengths and fluences have been shown to increase bacterial cell proliferation, and the effects on fibroblasts are not well established and vary according to wavelengths used. Despite this, PBM using blue light may be a viable alternative to drug treatment.

\section{Photobiomodulation for Diabetic Wound Healing}

Various studies have found PBM to be beneficial to diabetic wound healing (Table 1). PBM has promoted and sped up repair in non-healing ulcers. Al-Watban [49] reported on the use of different lasers with wavelengths in the visible to NIR spectra $(532,633,810,980$, and 10,600 nm) and polychromatic LED clusters (510-872 nm, visible to infrared). Streptozotocin-induced Sprague-Dawley rats were subjected to a full-thickness wound $\left(102.5 \pm 9 \mathrm{~mm}^{2}\right)$ or a burn $\left(148 \pm 12.5 \mathrm{~mm}^{2}\right)$ and then treated with PBM three times a week at different fluencies $\left(5,10,20\right.$, and $\left.30 \mathrm{~J} / \mathrm{cm}^{2}\right)$. It was concluded that the best treatment option for both diabetic wounds and burns was with a laser at a wavelength of $633 \mathrm{~nm}$ with $38.5 \%$ and $53.4 \%$ improvements, respectively. A dose (fluence) of $4.71 \mathrm{~J} / \mathrm{cm}^{2}$ for diabetic burns, and $2.35 \mathrm{~J} / \mathrm{cm}^{2}$ per dose for diabetic wound healing administered three times a week was recommended. Eissa and Salih [50] irradiated diabetic wounded rats $\left(632.8 \mathrm{~nm}, 4 \mathrm{~mW} / \mathrm{cm}^{2}\right)$ five times a week until the wounds healed. Irradiated diabetic wounds took 21 days to heal, whereas non-treated control wounds took 40 to 60 days to heal.

Chronic diabetic wounds have shown decreased levels of cytokines and growth factors essential to wound healing [51]. PBM has been show to promote the synthesis and release of some of these under diabetic conditions, including EGF, IL-6, bFGF, platelet-derived growth factor (PDGF), and transforming growth factor beta 1 (TGF- $\beta 1$ ). Jere et al. [43] demonstrated an increase in cell migration rate, proliferation, and viability in diabetic induced wounded fibroblast cells, which was ascribed to increased EGF, which in turn lead to activation of the receptor (EGFR) and the JAK/STAT pathway. They concluded that PBM at $660 \mathrm{~nm}\left(11 \mathrm{~mW} / \mathrm{cm}^{2}, 5 \mathrm{~J} / \mathrm{cm}^{2}\right)$ is able to intensify and regulate cellular autocrine signaling, leading to increased cell proliferation and migration. Esmaeelinejad and Bayat [52] irradiated human skin fibroblasts $\left(632.8 \mathrm{~nm} ; 0.66 \mathrm{~mW} / \mathrm{cm}^{2} ; 0.5,1\right.$, and $\left.2 \mathrm{~J} / \mathrm{cm}^{2}\right)$ in media that had different glucose concentrations (5.5 (physiological levels), 11.1 , and $15 \mathrm{mM} / \mathrm{L}$ ) and observed an 
increase in the release of intracellular cytokines IL-6 (at 0.5, 1, and $2 \mathrm{~J} / \mathrm{cm}^{2}$ ) and bFGF (at $2 \mathrm{~J} / \mathrm{cm}^{2}$ ). Khoo et al. [53] showed that PBM significantly augmented PDGF and up-regulated gene expression of FGF in diabetic mice skin fibroblasts when irradiated at a wavelength of $810 \mathrm{~nm}\left(10 \mathrm{~mW} / \mathrm{cm}^{2}\right)$ with a fluence of $1 \mathrm{~J} / \mathrm{cm}^{2}$. Ma et al. [54] irradiated streptozotocin-induced Wistar rats to a wavelength of $630 \mathrm{~nm}(5,10$, and $20 \mathrm{~mW} / \mathrm{cm}^{2} ; 3.6 \mathrm{~J} / \mathrm{cm}^{2}$ ) and found that PBM significantly altered TGF- $\beta 1$ and bFGF expression after 4 days. There was also an attenuation of the inflammatory response, greater reepithelization, mature granulation tissue (fibroblasts), and extensive collagen deposition, especially with irradiation of $20 \mathrm{~mW} / \mathrm{cm}^{2}$ [54].

Prolonged inflammation contributes to the pathophysiology of diabetic wound healing [55]. PBM has been shown to have anti-inflammatory effects under such conditions. Akyol and Güngörmüs [56] treated incisions made with a diode laser or a scalpel on the left side of the dorsum in streptozotocin-induced Wistar rats with PBM $\left(808 \mathrm{~nm}, 0.1 \mathrm{~W} / \mathrm{cm}^{2}, 10 \mathrm{~J} / \mathrm{cm}^{2}\right)$ for five sessions on alternative days. Rats were sacrificed at 10 (2 days after the last PBM treatment) and 20 days and the degree of reepithelialization and inflammation was investigated. There was a lower degree of reepithelialization and acute inflammation in the control group, with a significant increase in reepithelialization and diffuse acute inflammation in PBM treated groups. There was no statistically significant difference between the groups in inflammation and reepithelialization at day 20. PBM at $830 \mathrm{~nm}\left(5 \mathrm{~J} / \mathrm{cm}^{2}, 4.4 \mathrm{~mW} / \mathrm{cm}^{2}\right)$ resulted in a decrease in pro-inflammatory cytokines (TNF- $\alpha$ and IL-1 $\beta$ ) and apoptosis in diabetic wounded fibroblast cells [35]. Irradiation of the same cells to $660 \mathrm{~nm}$ $\left(11 \mathrm{~mW} / \mathrm{cm}^{2}, 5 \mathrm{~J} / \mathrm{cm}^{2}\right)$ resulted in decreased apoptosis and IL-1 $\beta$ [57]. There was also an increase in cellular viability and proliferation. Hypoxic cells also responded to PBM at the same parameters, and showed increased viability and proliferation, as well as decreased TNF- $\alpha$ [57].

During wound healing, the ECM is maintained by a balance between collagen production and ECM degradation to facilitate cellular migration and removal of debris. In the case of diabetes, this balance is negated; there is decreased ECM synthesis and increased ECM degradation [58]. Carvalho and colleagues [59] irradiated diabetic Wistar rats $\left(660 \mathrm{~nm}, 4 \mathrm{~J} / \mathrm{cm}^{2}\right)$ and found that PBM promoted healing by increasing collagen synthesis. Tatmatsu-Rocha et al. [60] irradiated $4 \mathrm{~cm}^{2}$ wounds in diabetic mice daily for 5 days (superpulsed AsGa laser, $904 \mathrm{~nm}, 40 \mathrm{~mW}, 304.8 \mathrm{~mW} / \mathrm{cm}^{2}, 18.288 \mathrm{~J} / \mathrm{cm}^{2}$ ). It was shown that there was increased collagen production, organization and angiogenesis, and decreased oxidative and nitrosative stress. Peplow et al. [61] irradiated wounded mice that represented a model of type $2 \mathrm{DM}$. Mice received a full thickness wound using a $5 \mathrm{~mm}$ punch. It was determined that PBM at a wavelength of $660 \mathrm{~nm}\left(4.7\right.$ to $6.3 \mathrm{~J} / \mathrm{cm}^{2}$, with 25,50 , or $\left.100 \mathrm{~mW}\right)$ increased granulation tissue formation in diabetic mice when irradiated daily for 7 days. Lau et al. [62] ascertained irradiation of diabetic rats at $808 \mathrm{~nm}\left(5 \mathrm{~J} / \mathrm{cm}^{2}\right)$ led to swifter wound contraction, and increased fibroblasts, granulation tissue, and collagen deposition. This occurred using three different power densities of $0.1,0.2$, and $0.3 \mathrm{~W} / \mathrm{cm}^{2}$, however, better results were seen at $0.1 \mathrm{~W} / \mathrm{cm}^{2}$. Aparecida Da Silva et al. [63] irradiated wounded diabetic rats to a wavelength of $660 \mathrm{~nm}\left(50 \mathrm{~mW}, 4 \mathrm{~J} / \mathrm{cm}^{2}\right)$ and found that PBM reduced the genetic expression of proteinases MMP-2 and -9 , and increased total collagen production, particularly collagen type-III. Ayuk et al. [64] showed increased collagen production when diabetic wounded fibroblast cells were irradiated at $660 \mathrm{~nm}\left(10.22 \mathrm{~mW} / \mathrm{cm}^{2}, 5 \mathrm{~J} / \mathrm{cm}^{2}\right)$. In similar studies, gene profiles showed that genes related to collagen (Collagen, type XI, and Collagen, type XIV) were up-regulated and various MMPs down-regulated (MMP-1, $-2,-8,-12,-14$, and -16) in response to laser irradiation. MMP inhibitors were also up-regulated (TIMP-1) [65]. When the same cells were irradiated at a different wavelength of $830 \mathrm{~nm}\left(10.76 \mathrm{~mW} / \mathrm{cm}^{2}, 5 \mathrm{~J} / \mathrm{cm}^{2}\right)$ PBM produced a stimulatory effect on various cell adhesion molecules, namely, cadherins, integrins, selectins and immunoglobulins [66].

A study on the effect of PBM on S. aureus infected wounds in diabetic rats was conducted by Ranjbar and colleagues [67]. Streptozotocin-induced male Wistar rats received $4 \mathrm{~cm}$ full-thickness linear incisions on the dorsal midline which were contaminated with $5 \times 10^{7} \mathrm{CFU} / \mathrm{mL}$ of S. aureus. The wounds were then closed with sutures. On the third day post-wounding, wounds were irradiated daily for 5 consecutive days using a laser with a wavelength of $685 \mathrm{~nm}\left(15 \mathrm{~mW}, 3 \mathrm{~J} / \mathrm{cm}^{2}\right.$, spot of 
$0.028 \mathrm{~cm}^{2}$ ); control rats were sham irradiated. PBM resulted in decreased bacterial numbers, with a significant decrease observed in the irradiated rats $(0.51 \times 10 \pm 0.2 \times 10 \mathrm{CFU} / \mathrm{mL})$ as compared to the controls $\left(8.4 \times 10^{7} \pm 1.8 \times 10^{7} \mathrm{CFU} / \mathrm{mL}\right)$. PBM also resulted in significantly shorter wound length (on days 14 and 21), and a significant increase in the number of macrophages, new blood vessels, fibroblasts, and collagen deposition. The breaking strength of the scars was also significantly increased in PBM treated rats [67]. This study has shown the potential of utilizing PBM in the treatment of infected diabetic wounds.

Covering of wounds with a transparent dressing may be required when performing PBM on wounds, especially when performing PBMT by a contact procedure. This is done to minimize wound damage caused by the tip of the device probe, to prevent cross contamination if irradiating multiple wounds, and to maximize irradiation [68]. Chung and colleagues [68] tested methods for dressing full-thickness excisional wounds that would be suitable for use with PBM in diabetic and nondiabetic mice. The combined use of Tegaderm HP dressing and Cavilon (protects the skin from adhesive stripping) and Mastisol (exceptional adhesive properties to benzoin compound tincture) adhesive agents was shown to be efficient for covering wounds of diabetic mice for over 14 days. Irradiated wounds had a very high rate $(>80 \%)$ of wound splinting (healing occurs mainly by reepithelization and granulation tissue formation) in diabetic mice, without recourse to invasive treatments, such as sutures. Tegaderm dressing has been shown to transmit $93 \%$ of laser light at a wavelength of $532 \mathrm{~nm}$, $94 \%$ at $1064 \mathrm{~nm}$, and $74 \%$ at $720-800 \mathrm{~nm}[69,70]$.

PBM has also been shown to be successful in human studies, with no reported side effects. Nteleki et al. [71] showed that PBM may be beneficial in the treatment of DFUs in combination with standard podiatric care and treatment. Patients with type 2 diabetes with a stable or worsening lower extremity ulcer that had been present for a minimum of 4 weeks were enrolled into a pilot study. Patients all received standard podiatric care, which consisted of wound cleaning and debridement, wound dressing, offloading, and infection control (antibiotics) if necessary. Patients were divided into three groups; group 1 received placebo PBM; group 2 received PBM of the ulcer; and group 3 received PBM of the ulcer and regional lymph nodes so as to increase lymph drainage. DFUs were irradiated twice a week for a maximum of 90 days with a LED cluster probe (630 and $850 \mathrm{~nm})$. Ulcers were irradiated after podiatric treatment and before dressing. Wounds in group 2 and 3 healed at a far more rapid rate than wounds in group 1 . The results of the study showed that PBM has the potential to stimulate and increase healing rates in combination with podiatric medicine.

Mathur and colleagues [72] irradiated $\left(660 \mathrm{~nm}, 3 \mathrm{~J} / \mathrm{cm}^{2}, 50 \mathrm{~mW} / \mathrm{cm}^{2}\right)$ non-infected grade I diabetic foot ulcers together with conventional treatments. Wound reduction was measured at two weeks and was found to be significantly reduced in 75\% of PBM treated ulcers (30-50\%); control wounds showed a decrease in wound area of less than $20 \%$ in approximately $80 \%$ of ulcers. There was also increased granulation tissue compared to control patients. Kaviani et al. [73] performed a randomized double-blind controlled clinical trial and treated stage I and II DFUs $\left(685 \mathrm{~nm}, 50 \mathrm{~mW} / \mathrm{cm}^{2}, 10 \mathrm{~J} / \mathrm{cm}^{2}\right)$ six times per week for two weeks, and then every other day until healed. It was found that there was a reduction in ulcer size by the 2 nd and 4 th week. A similar study showed a decrease in ulcer size in type 2 diabetic patients ( $40.24 \%$ as compared with $11.87 \%$ for the control group) [74]. Ruh et al. [75] treated pressure ulcers, classified as degree III and IV according to the National Pressure Ulcer Advisory Panel (NPUAP), with PBM at $660 \mathrm{~nm}\left(100 \mathrm{~mW}, 2 \mathrm{~J} / \mathrm{cm}^{2}\right)$ once a day, with intervals of $24 \mathrm{~h}$, for a total of 12 applications. Wound closure analysis revealed improvement of the granulation tissue size up to $50 \%$, and gene analysis of ulcer border tissue obtained through biopsy showed a down-regulation in TN-F $\alpha$ and up-regulation in VEFG and TGF- $\beta$. It should be noted that this study did not include controls, however, despite this, PBM still showed promise of being beneficial to diabetic wound healing. 
Table 1. Effect of Photobiomodulation (PBM) on diabetic wound healing.

\begin{tabular}{|c|c|c|c|c|c|c|c|c|c|}
\hline \multicolumn{2}{|c|}{ Wavelength (nm) } & Dose $\left(\mathrm{J} / \mathrm{cm}^{2}\right)$ & $\begin{array}{l}\text { Power Density } \\
\left(\mathrm{mW} / \mathrm{cm}^{2}\right)\end{array}$ & $\begin{array}{l}\text { Frequency (Pulse } \\
\text { Duration) }\end{array}$ & $\begin{array}{l}\text { Treatment } \\
\text { Schedule }\end{array}$ & Wound Model & Outcome Measures & Outcomes/Observations & Reference \\
\hline \multirow{5}{*}{ Lasers } & 532 & \multirow{6}{*}{$5,10,20$, and 30} & $20.4(532 \mathrm{~nm})$ & \multirow{6}{*}{-} & \multirow{6}{*}{$\begin{array}{l}\text { Three times } \\
\text { a week. }\end{array}$} & \multirow{6}{*}{$\begin{array}{l}\text { STZ-induced } \\
\text { Sprague-Dawley rats. } \\
\text { Full-thickness wounds } \\
\text { 102.5 } \pm 9 \mathrm{~mm}^{2}, \text { or a burn } \\
\left(148 \pm 12.5 \mathrm{~mm}^{2}\right) .\end{array}$} & \multirow{6}{*}{$\begin{array}{l}\text { Wound- or } \\
\text { burn-healing percentages. }\end{array}$} & \multirow{6}{*}{$\begin{array}{l}\text { Significant wound ( } 38.5 \%) \text { and burn healing } \\
(53.4 \%) \text { were demonstrated at } 633 \mathrm{~nm} \text { with } \\
\left.4.71 \mathrm{~J} / \mathrm{cm}^{2} \text { (actual dose) }\right)^{*} \text { for wounds and } \\
2.35 \mathrm{~J} / \mathrm{cm}^{2} \text { (actual dose) for burns. }\end{array}$} & \multirow{6}{*}{ [49] } \\
\hline & 633 & & $15.56(633 \mathrm{~nm})$ & & & & & & \\
\hline & 810 & & $22.22(810 \mathrm{~nm})$ & & & & & & \\
\hline & 980 & & $22.22(980 \mathrm{~nm})$ & & & & & & \\
\hline & 10,600 & & $66.37(10,600 \mathrm{~nm})$ & & & & & & \\
\hline LED cluster & $510-872$ & & 13.6 (LED cluster) & & & & & & \\
\hline \multicolumn{2}{|c|}{632.8} & - & 4 & - & $\begin{array}{l}\text { Five times a } \\
\text { week until } \\
\text { healed. }\end{array}$ & $\begin{array}{l}\text { Alloxan-induced Wistar } \\
\text { rats with full-thickness, } \\
\text { excisional wound } \\
\text { (diameter } 2.5 \pm 0.2 \mathrm{~cm} \text { ) on } \\
\text { the dorsum. }\end{array}$ & Wound diameters. & $\begin{array}{l}\text { Wounds healed within } 21 \text { days in irradiated } \\
\text { animals, and took up to } 60 \text { days to heal in } \\
\text { the controls. }\end{array}$ & [50] \\
\hline \multicolumn{2}{|l|}{660} & 5 & 11 & - & $\begin{array}{l}\text { Irradiated } \\
\text { once and left } \\
\text { to incubate for } \\
24 \mathrm{~h} \text {. }\end{array}$ & $\begin{array}{c}\text { Normal, wounded } \\
\text { (scratch assay), diabetic } \\
\text { (hyperglycemia, } \\
22.6 \mathrm{mMol} / \mathrm{L} \text { ) and diabetic } \\
\text { wounded (scratch assay } \\
\text { and hyperglycemia, } \\
22.6 \mathrm{mMl} / \mathrm{L} \text { ) fibroblast } \\
\text { cell models. }\end{array}$ & $\begin{array}{l}\text { Cellular migration, } \\
\text { proliferation, viability, } \\
\text { EGF, p-EGFR, p-JAK2, } \\
\text { p-STAT1 and p-STAT5. }\end{array}$ & $\begin{array}{l}\text { Increased migration rate in wounded and } \\
\text { diabetic wounded models. Increased } \\
\text { proliferation and viability in all models. } \\
\text { Increased EGF and p-JAK2 in wounded, } \\
\text { diabetic and diabetic wounded models, and } \\
\text { increased p-EGFR, p-STAT1 and p-STAT5 in } \\
\text { all models. }\end{array}$ & [43] \\
\hline \multicolumn{2}{|c|}{632.8} & $0.5,1$, and 2 & 0.66 & - & $\begin{array}{l}\text { Cells } \\
\text { irradiated } \\
\text { once daily for } \\
\text { three } \\
\text { consecutive } \\
\text { days. }\end{array}$ & $\begin{array}{l}\text { Human skin fibroblasts } \\
\text { grown under } \\
\text { hyperglycemic (11.1, and } \\
15 \mathrm{mM} / \mathrm{L} \text { glucose) } \\
\text { conditions. }\end{array}$ & IL-6 and bFGF & $\begin{array}{l}0.5,1 \text {, and } 2 \mathrm{~J} / \mathrm{cm}^{2} \text { stimulates the release of } \\
\text { IL-6 } 6 \text { from fibroblasts cultured in } \\
\text { hyperglycemic }(15 \mathrm{mM} / \mathrm{L}) \text { media. } 2 \mathrm{~J} / \mathrm{cm}^{2} \\
\text { significantly increased the release of bFGF } \\
\text { from fibroblasts cultured in hyperglycemic } \\
\text { (11.1 ad } 15 \mathrm{mM} / \mathrm{L}) \text { media. }\end{array}$ & [52] \\
\hline \multicolumn{2}{|l|}{810} & 1 & 10 & - & $\begin{array}{l}\text { Single } \\
\text { irradiation } \\
\text { and incubated } \\
\text { for } 1 \mathrm{~h} .\end{array}$ & $\begin{array}{l}\text { Skin fibroblasts isolated } \\
\text { from male Balb/c mice. }\end{array}$ & $\begin{array}{l}\text { RT-qPCR for VEGF, EGF, } \\
\text { PDGF, FGF. }\end{array}$ & $\begin{array}{l}\text { Significant increase in FGF expression; PDGF } \\
\text { expression increased, but was not significant. }\end{array}$ & [53] \\
\hline
\end{tabular}


Table 1. Cont.

\begin{tabular}{|c|c|c|c|c|c|c|c|c|}
\hline Wavelength (nm) & Dose $\left(\mathrm{J} / \mathrm{cm}^{2}\right)$ & $\begin{array}{l}\text { Power Density } \\
\left(\mathrm{mW} / \mathrm{cm}^{2}\right)\end{array}$ & $\begin{array}{l}\text { Frequency (Pulse } \\
\text { Duration) }\end{array}$ & $\begin{array}{l}\text { Treatment } \\
\text { Schedule }\end{array}$ & Wound Model & Outcome Measures & Outcomes/Observations & Reference \\
\hline 630 & 3.6 & 5,10 , and 20 & - & $\begin{array}{l}\text { Five times a } \\
\text { week for two } \\
\text { weeks. }\end{array}$ & $\begin{array}{l}\text { STZ-induced male Wistar } \\
\text { rats with two } 100 \mathrm{~cm}^{2} \\
\text { incisions each side on } \\
\text { the dorsum. }\end{array}$ & $\begin{array}{l}\text { Percentage wound } \\
\text { closure, histology } \\
\text { (PMNL, reepithelization, } \\
\text { fibroblasts, new vessels, } \\
\text { and collagen synthesis), } \\
\text { bFGF and TGF- } \beta 1 \text {. }\end{array}$ & $\begin{array}{l}\text { Wounds irradiated with } 20 \mathrm{~mW} / \mathrm{cm}^{2} \text { closed } \\
\text { significantly faster at } 3 \text { days as compared to } \\
\text { controls, while at } 6 \text { and } 9 \text { days all three PBM } \\
\text { groups closed significantly faster, while at } \\
12 \text { days there were no differences. } \\
\text { Histology showed increased collagen fibers at } \\
\text { day } 4 \text { in wounds irradiated with } 10 \text { and } 20 \\
\mathrm{~mW} / \mathrm{cm}^{2} \text {. At day } 8 \text {, there was attenuated } \\
\text { inflammation, mature granulation tissue, } \\
\text { extensive collagen deposition, and greater } \\
\text { reepithelization in all the PBM groups, while } \\
\text { the control group showed more inflammatory } \\
\text { exudate and fresh granulation tissue. At day } \\
14, \text { almost all the wounds in all PBM and } \\
\text { control groups were covered by new epithelial } \\
\text { cells, granulation tissue was replaced with } \\
\text { fibrous scar, fibroblasts decreased, and } \\
\text { intercellular collagen content increased. There } \\
\text { was an increase in new vessels in wounds } \\
\text { irradiated with } 5 \text { and } 20 \mathrm{~mW} / \mathrm{cm}^{2} \text {. } \\
\text { bFGF significantly increased in all three PBM } \\
\text { groups, but was not evident tat } 14 \text { days. } \\
\text { Wounds irradiated with } 10 \mathrm{~mW} / \mathrm{cm}^{2} \text { showed } \\
\text { significant increase in TGF- } \beta 1 \text { at } 4 \text { days. }\end{array}$ & [54] \\
\hline 808 & 2 (Total of 10 ) & 100 (PBM) & - & $\begin{array}{l}\text { Irradiated for } \\
\text { five sessions }\end{array}$ & $\begin{array}{l}\text { STZ-induced Wistar rats } \\
\text { received one } 15 \mathrm{~cm} \text { long } \\
\text { incision on the left hand } \\
\text { side (group 3) and one on } \\
\text { the right hand side (group } \\
\text { 2), both induced by a laser, } \\
\text { and one incision on the } \\
\text { right hand side induced by } \\
\text { a scalpel (group 1). } \\
\text { Wounds were sutured and } \\
\text { single wound on left hand } \\
\text { side received PBM } \\
\text { (group 3). }\end{array}$ & $\begin{array}{l}\text { Histology slides } \\
\text { (hematoxylin-eosin) } \\
\text { examined and } \\
\text { reepithelialization and } \\
\text { inflammation graded } \\
1 \text { to } 4 \text {. }\end{array}$ & $\begin{array}{l}\text { At day } 10 \text { there was increased reepithelization } \\
\text { in groups } 2 \text { and } 3 \text {, and acute inflammation in } \\
\text { groups } 1 \text { and } 2 \text {. In the group } 3 \text { (PBM treated), } \\
\text { fibroblast proliferation was evident. There } \\
\text { were no differences at day } 20 .\end{array}$ & [56] \\
\hline
\end{tabular}


Table 1. Cont.

\begin{tabular}{|c|c|c|c|c|c|c|c|c|}
\hline Wavelength (nm) & Dose $\left(\mathrm{J} / \mathrm{cm}^{2}\right)$ & $\begin{array}{l}\text { Power Density } \\
\left(\mathrm{mW} / \mathrm{cm}^{2}\right)\end{array}$ & $\begin{array}{l}\text { Frequency (Pulse } \\
\text { Duration) }\end{array}$ & $\begin{array}{l}\text { Treatment } \\
\text { Schedule }\end{array}$ & Wound Model & Outcome Measures & Outcomes/Observations & Reference \\
\hline 830 & 5 & 4.4 & - & $\begin{array}{l}\text { Irradiated } \\
\text { once and left } \\
\text { to incubate for } \\
\text { various times } \\
\text { ( } 15 \text { mini } ; 1 \mathrm{~h} \text {; } \\
24 \mathrm{~h} ; 48 \mathrm{~h})\end{array}$ & $\begin{array}{l}\text { Normal, wounded (scratch } \\
\text { assay), diabetic } \\
\text { (hyperglycemia, } 22.6 \\
\text { mMol/L) and diabetic } \\
\text { wounded (scratch assay } \\
\text { and hyperglycemia, 22.6 } \\
\text { mMol/L) fibroblast } \\
\text { cell models. }\end{array}$ & $\begin{array}{l}\text { Proliferation, apoptosis, } \\
\text { viability, NO, ROS, } \\
\text { cytokines (TNF- } \alpha \text {; } \\
\text { IL-1 } \beta \text {; IL-6) }\end{array}$ & $\begin{array}{l}\text { PBM had no effect on cellular viability (above } \\
95 \%) \text {, and significantly increased proliferation } \\
\text { at } 24 \mathrm{~h} \text { and } 48 \mathrm{~h} \text { in normal wounded ( } 51 \% \text { and } \\
19 \% \text {, respectively) and diabetic cells }(53 \% \text { and } \\
28 \% \text { respectively). Twenty-four hours } \\
\text { post-irradiation there was a significant } \\
\text { decrease in apoptosis in normal wounded } \\
(82 \% \text { and diabetic wounded cellls }(31 \%) \text {. } \\
\text { Significant decrease in all cell models in } \\
\text { TNF- } 1 \mathrm{~h} \text { post-irradiation was observed. } \\
\text { This decrease was still evident in normal } \\
\text { wounded and diabetic wounded cells at } 24 \mathrm{~h} \text {. } \\
\text { IL-1 } 1 \beta \text { was decreased in normal cells at } 1 \mathrm{~h} \text { and } \\
\text { in diabetic wounded cells at } 24 \mathrm{~h} \text {. There were } \\
\text { no significant changes in IL-6. } \\
\text { There was a rapid significant increase in NO } \\
\text { in all irradiated cells, which was seen } 15 \text { in } \\
\text { post-irradiation but not at } 1 \mathrm{~h} \text {. There was also } \\
\text { more ROS in irradiated cellls } 15 \text { min } \\
\text { post-irradiation. }\end{array}$ & [35] \\
\hline 636 & 5 & 11 & - & $\begin{array}{l}\text { Irradiated } \\
\text { once and left } \\
\text { for } 1 \mathrm{~h} \text { or } 24 \mathrm{~h} \text {. }\end{array}$ & $\begin{array}{l}\text { Normal, wounded (scratch } \\
\text { assay), diabetic wounded } \\
\text { (scratch assay and } \\
\text { hyperglycemia, } 22.6 \\
\text { mMol/L), and hypoxic } \\
\text { (without FBS for } 24 \mathrm{~h} \text { and } \\
\text { anaerobic incubation } \\
\text { for } 24 \mathrm{~h} \text {. }\end{array}$ & $\begin{array}{l}\text { Morphology, viability, } \\
\text { proliferation, apoptosis, } \\
\text { pro-inflammatory } \\
\text { cytokines (TNF-a, IL-1 } 1 \beta, \\
\text { and IL-6) and NF-kB } \\
\text { translocation. }\end{array}$ & 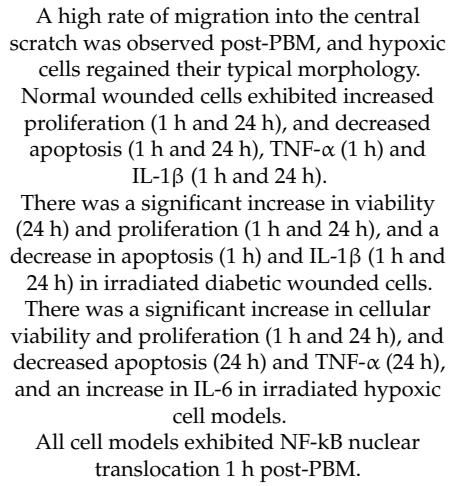 & [57] \\
\hline 660 & 10 & - & - & $\begin{array}{l}\text { Treated daily } \\
\quad \text { for } 3 \\
7 \text { or } 14 \text { days. }\end{array}$ & $\begin{array}{l}\text { Alloxan-induced adult } \\
\text { male albino Wistar rats } \\
\text { with } 8 \mathrm{~mm} \text { diameter } \\
\text { punch wound. }\end{array}$ & $\begin{array}{l}\text { Histology } \\
\text { (hematoxylin-eosin and } \\
\text { Masson's trichrome } \\
\text { staining, and } \\
\text { immunohistochemical } \\
\text { stains for macrophages). }\end{array}$ & $\begin{array}{l}\text { There was significantly more collagen and } \\
\text { less macrophages in PBM-treated wounds on } \\
\text { days } 3,7 \text { and } 14 \text { as compared to unirradiated } \\
\text { control rats. }\end{array}$ & [59] \\
\hline
\end{tabular}


Table 1. Cont.

\begin{tabular}{|c|c|c|c|c|c|c|c|c|}
\hline Wavelength (nm) & Dose $\left(\mathrm{J} / \mathrm{cm}^{2}\right)$ & $\begin{array}{l}\text { Power Density } \\
\left(\mathrm{mW} / \mathrm{cm}^{2}\right)\end{array}$ & $\begin{array}{c}\text { Frequency (Pulse } \\
\text { Duration) }\end{array}$ & $\begin{array}{l}\text { Treatment } \\
\text { Schedule }\end{array}$ & Wound Model & Outcome Measures & Outcomes/Observations & Reference \\
\hline 904 & 18.288 & 304.8 & $\begin{array}{l}9500 \mathrm{~Hz} \text { with } \\
\text { pulse duration of } \\
60 \mathrm{~s} \text { and } 20 \% \\
\text { duty cycle }\end{array}$ & $\begin{array}{l}\text { Daily for } 5 \\
\text { consecutive } \\
\text { days. }\end{array}$ & $\begin{array}{l}\text { STZ-induced male Swiss } \\
\text { mice with } 4 \mathrm{~cm}^{2} \text { surgical } \\
\text { wound in the posterior iliac } \\
\text { crest reaching down to } \\
\text { the hypodermis. }\end{array}$ & $\begin{array}{c}\text { Histology } \\
\text { (hematoxylin-eosin and } \\
\text { Masson's trichrome } \\
\text { staining). Biochemical } \\
\text { determinations included } \\
\text { TBARS (lipid } \\
\text { peroxidation) catalase } \\
\text { activity and nitrite } \\
\text { concentration. }\end{array}$ & $\begin{array}{c}\text { Histology results showed a fair number of } \\
\text { fusiform fibroblasts and increased blood } \\
\text { vessels in irradiated diabetic mice, with an } \\
\text { intense deposition of a more organized } \\
\text { collagen matrix. } \\
\text { There was a significant reduction of nitrite } \\
\text { levels and TBARS, and a significant increase } \\
\text { in catalase activity. }\end{array}$ & [60] \\
\hline 660 & $4.7-6.3(2 \mathrm{~J} / \mathrm{day})$ & $\begin{array}{c}58-78(25 \mathrm{~mW}) \\
116-156(50 \mathrm{~mW}) \\
233-313(100 \mathrm{~mW})\end{array}$ & - & $\begin{array}{l}\text { Daily for } 7 \\
\text { consecutive } \\
\text { days. }\end{array}$ & $\begin{array}{l}\text { Diabetic mice (BKS.Cg-m } \\
\text { p//p Leprdb/J), which were } \\
\text { leptin receptor deficient } \\
\text { and represented a model of } \\
\text { type-2 diabetes, received } \\
\text { full thickness circular } \\
\text { wounds using a } 5 \mathrm{~mm} \\
\text { diameter skin punch. }\end{array}$ & $\begin{array}{c}\text { Histology slides } \\
\text { (hematoxylin-eosin) } \\
\text { graded (1-15), } \\
\text { Photographic images } \\
\text { were analyzed for dermal } \\
\text { gap and epithelial gap. }\end{array}$ & $\begin{array}{l}\text { All irradiations increased the extent of } \\
\text { epithelial regrowth, granulation tissue, and } \\
\text { collagen, and induced a greater } \\
\text { inflammatory response. }\end{array}$ & [61] \\
\hline 808 & 5 & $\begin{array}{c}100 \text { (G1), } 200 \text { (G2), } \\
300 \text { (G3) }\end{array}$ & - & $\begin{array}{l}\text { Daily for } 9 \\
\text { consecutive days. }\end{array}$ & $\begin{array}{l}\text { STZ-induced Sprague } \\
\text { Dawley rats received full } \\
\text { thickness circular wounds } \\
\text { on the dorsal using a } \\
6 \mathrm{~mm} \text { punch. }\end{array}$ & $\begin{array}{l}\text { Percentage wound } \\
\text { contraction, and } \\
\text { histology slides } \\
\text { (hematoxylin-eosin). }\end{array}$ & $\begin{array}{l}\text { Percentage wound contraction increased for } \\
\text { all irradiated groups on days } 3 \text { and } 6 . \\
\text { Histology showed increased proliferation of } \\
\text { epithelium near the wound surface, with } \\
\text { denser connective tissue, angiogenesiss, and } \\
\text { intense inflammatory cells at day } 3 \text {. By day } 6 \text {, } \\
\text { there was intense granulation tissue } \\
\text { formation (G1) with a minimal to mild } \\
\text { inflammatory infiltrate with restoration of } \\
\text { epidermis on the wound surface. On day } 9 \\
\text { the epidermis was covered in both irradiated } \\
\text { mice and controls, with formation of stratified } \\
\text { keratin at the superficial layer. }\end{array}$ & [62] \\
\hline 660 & 4 & 1430 & - & - & $\begin{array}{l}\text { STZ-induced male Wistar } \\
\text { rats received full thickness } \\
\text { circular wounds on the } \\
\text { dorsal using an } \\
8 \mathrm{~mm} \text { punch. }\end{array}$ & $\begin{array}{l}\text { Histology } \\
\text { (hematoxylin-eosin and } \\
\text { Masson's trichrome and } \\
\text { Picrosirius Red staining) } \\
\text { and RT-qPCR (MMP-2 } \\
\text { and MMP-9) } \\
\end{array}$ & $\begin{array}{l}\text { Results showed increased, denser total } \\
\text { collagen, with significant increases in type I. } \\
\text { Genetic testing showed decreased expression } \\
\text { of the proteinases MMP-2 and }-9 .\end{array}$ & [63] \\
\hline 660 & 5 & 10.22 & - & $\begin{array}{l}\text { Irradiated } \\
\text { once and left } \\
\text { for } 48 \text { or } 72 \mathrm{~h} \text {. }\end{array}$ & $\begin{array}{c}\text { Normal, and diabetic } \\
\text { wounded (scratch assay } \\
\text { and hyperglycemia, } 22.6 \\
\mathrm{mMol} / \mathrm{L}) .\end{array}$ & $\begin{array}{l}\text { Viability, proliferation, } \\
\text { collagen type I. }\end{array}$ & $\begin{array}{l}\text { Cellular viability was increased in irradiated } \\
\text { diabetic wounded cells } 48 \mathrm{~h} \text { and } 72 \mathrm{~h} \\
\text { post-PBM. Proliferation results showed an } \\
\text { increase at } 48 \mathrm{~h} \text { and a decrease at } 72 \mathrm{~h} \\
\text { (attributed to over confluence). There was a } \\
\text { significant increase in collagen type I. }\end{array}$ & [64] \\
\hline 660 & 5 & 10.22 & - & $\begin{array}{l}\text { Irradiated } \\
\text { once and left } \\
\quad \text { for } 48 .\end{array}$ & $\begin{array}{l}\text { Normal, wounded (scratch } \\
\text { assay), diabetic wounded } \\
\text { (scratch assay and } \\
\text { hyperglycemia, } \\
22.6 \mathrm{mMol} / \mathrm{L} \text { ). }\end{array}$ & $\begin{array}{l}\text { Gene Expression } \\
\text { Profiling of } 84 \text { genes } \\
\text { (RT-qPCR using } \\
\text { gene array- } \\
\text { extracellular matrix). }\end{array}$ & $\begin{array}{l}\text { Genes related to Collagen, type XI and XIV } \\
\text { were up-regulated, while MMP1, }-2,-8,-12, \\
-14, \text { and }-16 \text { were down-regulated. TIMP1 was } \\
\text { also up-regulated. }\end{array}$ & [65] \\
\hline
\end{tabular}


Table 1. Cont.

\begin{tabular}{|c|c|c|c|c|c|c|c|c|}
\hline Wavelength (nm) & Dose $\left(\mathrm{J} / \mathrm{cm}^{2}\right)$ & $\begin{array}{c}\text { Power Density } \\
\left(\mathrm{mW} / \mathrm{cm}^{2}\right)\end{array}$ & $\begin{array}{l}\text { Frequency (Pulse } \\
\text { Duration) }\end{array}$ & $\begin{array}{l}\text { Treatment } \\
\text { Schedule }\end{array}$ & Wound Model & Outcome Measures & Outcomes/Observations & Reference \\
\hline 830 & 5 & 10.76 & - & $\begin{array}{l}\text { Irradiated } \\
\text { once and left } \\
\quad \text { for } 48 .\end{array}$ & $\begin{array}{c}\text { Normal, and diabetic } \\
\text { wounded (scratch assay } \\
\text { and hyperglycemia, } 22.6 \\
\mathrm{mMol} / \mathrm{L}) .\end{array}$ & $\begin{array}{l}\text { Gene Expression } \\
\text { Profiling of cellular } \\
\text { adhesion molecules } \\
\text { (RT-qPCR using } \\
\text { gene array). }\end{array}$ & $\begin{array}{l}\text { Up-regulation of selectin E, selectin L, } \\
\text { vascular cell adhesion molecule 1, } \\
\text { Sarcoglycan (epsilon), and versican. }\end{array}$ & [66] \\
\hline 685 & 3 & 535.7 & - & $\begin{array}{l}\text { Daily for five } \\
\text { consecutive } \\
\text { days. }\end{array}$ & $\begin{array}{l}\text { STZ-induced male Wistar } \\
\text { rats received a } 4 \mathrm{~cm} \text { full } \\
\text { thickness linear incision on } \\
\text { the lumbar region. Wounds } \\
\text { were contaminated with } 5 \\
\times 10^{7} \mathrm{CFU} / \mathrm{mL} \text { of } S \text {. aureus, } \\
\text { sutured and left for } 48 \mathrm{~h} \text {. }\end{array}$ & $\begin{array}{l}\text { Macroscopic evaluation, } \\
\text { bacteriological analysis, } \\
\text { and histology. }\end{array}$ & $\begin{array}{c}\text { Bacterial inhibition occurred following PBM, } \\
\text { with significantly decreased bacterial } \\
\text { numbers in PBM group }\left(0.51 \times 10^{1} \mathrm{CFU} / \mathrm{mL}\right) \\
\text { compared to controls }\left(8.4 \times 10^{7} \mathrm{CFU} / \mathrm{mL}\right) \text {. } \\
\text { There was a significant decrease in wound } \\
\text { length on days } 14 \text { and } 21 \text {. PMB treated } \\
\text { infected wounds had increased } \\
\text { epithelialization, fibroblasts, collagen, } \\
\text { neoangiogenesis and scar breaking strength. }\end{array}$ & [67] \\
\hline $\begin{array}{l}\text { LED cluster probe: } 3 \times 630 \mathrm{~nm} \\
\text { LEDs and } 8 \times 830 \mathrm{LEDs}\end{array}$ & 3 per spot & 75 & $\begin{array}{l}\text { Pulsed: } \\
\text { continuous ratio } \\
\text { 30:70\%. Wound } \\
\text { protocol: 292, 930, } \\
\text { 1174, } 1520,1574, \\
\text { 1604, } 4788, \text {, 6352 } \\
\text { Hz. Muscle } \\
\text { protocol (lymph } \\
\text { nodes): } 292,588, \\
\text { 1520, } 1604,1756, \\
1760,9396 \mathrm{~Hz} .\end{array}$ & $\begin{array}{l}\text { Irradiated } \\
\text { treated twice a } \\
\text { week }(72 \mathrm{~h} \\
\text { between } \\
\text { treatments) } \\
\text { for a } \\
\text { maximum of } \\
90 \text { days. }\end{array}$ & $\begin{array}{l}\text { Adult patients with type 2 } \\
\text { DM and lower limb ulcers } \\
\text { of at least } 4 \text { weeks' } \\
\text { duration. Patients were } \\
\text { divided into three groups: } \\
\text { placebo PBM (group } \\
\text { 1-control); PBM of ulcer } \\
\text { (group 2; PBM of ulcer and } \\
\text { regional lymph nodes } \\
\text { (group 3). All groups } \\
\text { received standard podiatric } \\
\text { care (cleaning, } \\
\text { debridement, dressing, } \\
\text { off-loading, and antibiotics } \\
\text { if necessary). }\end{array}$ & $\begin{array}{l}\text { Visual examination of } \\
\text { wounds and digital } \\
\text { photography (ulcer size } \\
\text { and area granulation). }\end{array}$ & $\begin{array}{l}\text { Combination of podiatric care and PBM } \\
\text { yields the potential to stimulate and increase } \\
\text { healing rates of chronic diabetic ulcers. Forty } \\
\text { percent of ulcers treated with PBM were } \\
\text { completely resolved within } 8 \text { weeks, with no } \\
\text { reported adverse effects, whereas only } 10 \% \text { of } \\
\text { control wounds healed completely within the } \\
90 \text {-day study period. Group } 2 \text { and group } 3 \\
\text { patients reported a significant decrease in } \\
\text { ulcer discomfort and experienced occasional } \\
\text { sharp pains which may be consistent with } \\
\text { other clinical studies that have shown that } \\
\text { PBM promoted an increase in nerve } \\
\text { functional abilities and regeneration. }\end{array}$ & [71] \\
\hline 660 & 3 per spot & 50 & - & $\begin{array}{l}\text { Irradiated } \\
\text { daily for } \\
15 \text { days. }\end{array}$ & $\begin{array}{l}\text { Patients with Type 2 DM } \\
\text { with Meggitt- Wagner } \\
\text { grade I ulcers of at least } 6 \\
\text { weeks' duration. Patients } \\
\text { were divided into two } \\
\text { groups: PBM and control. } \\
\text { All wounds received } \\
\text { standard care involving } \\
\text { debridement, slough } \\
\text { excision and betadine } \\
\text { solution dressings. Prior to } \\
\text { PBM wounds were cleaned } \\
\text { and gauze dried. } \\
\text { Antibiotics were } \\
\text { administered if necessary. }\end{array}$ & $\begin{array}{l}\text { Visual examination of } \\
\text { wounds and digital } \\
\text { photography (wound } \\
\text { area and wound } \\
\text { contraction). }\end{array}$ & $\begin{array}{l}\text { Wound size in both groups decreased over the } \\
\text { 15-day period, with more healing noted in } \\
\text { PBM treated wounds. Ulcers of the PBM } \\
\text { group had more granulation tissue, while } \\
\text { ulcers in the control group had more visible } \\
\text { pus. PBM treated ulcers showed a significant } \\
\text { reduction in wound area }(37.3 \pm 9 \%) \text { as } \\
\text { compared to control groups }(15 \pm 5 \% \text { ), and } \\
\text { approximately } 75 \% \text { of these PBM treated } \\
\text { wounds showed a reduction of } 30-50 \% \text { within } \\
\text { the } 15 \text { days, compared to }<20 \% \text { in } \\
\text { approximately } 80 \% \text { of control wounds. }\end{array}$ & [72] \\
\hline
\end{tabular}


Table 1. Cont.

\begin{tabular}{|c|c|c|c|c|c|c|c|c|}
\hline Wavelength (nm) & Dose $\left(\mathrm{J} / \mathrm{cm}^{2}\right)$ & $\begin{array}{c}\text { Power Density } \\
\left(\mathrm{mW} / \mathrm{cm}^{2}\right)\end{array}$ & $\begin{array}{l}\text { Frequency (Pulse } \\
\text { Duration) }\end{array}$ & $\begin{array}{l}\text { Treatment } \\
\text { Schedule }\end{array}$ & Wound Model & Outcome Measures & Outcomes/Observations & Reference \\
\hline 685 & 10 & 50 & - & $\begin{array}{c}\text { Irradiated six } \\
\text { times per } \\
\text { week for } 2 \\
\text { weeks, and } \\
\text { then every } \\
\text { other day } \\
\text { until healed. }\end{array}$ & $\begin{array}{l}\text { Randomized double-blind } \\
\text { controlled clinical trial and } \\
\text { treated stage I and II } \\
\text { diabetic foot ulcers. } \\
\text { Patients were divided into } \\
\text { two groups: PBM and } \\
\text { control (placebo). All } \\
\text { ulcers received standard } \\
\text { care (debridement, } \\
\text { off-loading, dressings and } \\
\text { antibiotics). }\end{array}$ & $\begin{array}{l}\text { Digital photography, } \\
\text { peripheral neuropathy, } \\
\text { and arterial ultrasound if } \\
\text { deemed necessary. }\end{array}$ & $\begin{array}{l}\text { Two and } 4 \text { weeks into the study, the decline in } \\
\text { ulcer size in PBM treated ulcers compared } \\
\text { with the baseline was significantly greater } \\
\text { than in the placebo group ( } 58 \pm 10.4 \% \text { vs. } 23.5 \\
\pm 14.1 \% \text { a } 2 \text { weeks and }(73.7 \pm \pm 10.2 \% \text { vs. } 47.3 \\
\pm 1.4 \% \text {, respectively). By } 20 \text { weeks, a larger } \\
\text { number of PBM treated ulcers displayed } \\
\text { complete healing, and the mean time of } \\
\text { healing was lower (results were } \\
\text { however insignificant). }\end{array}$ & [73] \\
\hline $\begin{array}{l}\text { Multidiode cluster probe } \\
\text { (wavelength/s not provided) }\end{array}$ & $2-4$ & $(60 \mathrm{~mW})$ & $5 \mathrm{kHz}$ & $\begin{array}{l}\text { Irradiated } \\
\text { daily for } \\
15 \text { days. }\end{array}$ & $\begin{array}{l}\text { Type } 2 \text { DM patients with } \\
\text { Meggitt- Wagner grade I } \\
\text { ulcers of at least } 4 \text { weeks' } \\
\text { duration. Patients were } \\
\text { divided into two groups: } \\
\text { PBM and control (placebo). } \\
\text { Ulcers were subjected to } \\
\text { debridement, off-loading } \\
\text { and antibiotics } \\
\text { administered if necessary. } \\
\text { Ulcers were dressed daily } \\
\text { with wet saline or betadine. }\end{array}$ & $\begin{array}{l}\text { Ulcer area/percent } \\
\text { reduction in the size. }\end{array}$ & $\begin{array}{l}\text { At the end of the study period ( } 15 \text { days), there } \\
\text { was no significant difference between PBM } \\
\text { and control group with respect to wound area } \\
\left(1564.79 \mathrm{~mm}^{2} \text { for PBM and } 2424.75 \mathrm{~mm}^{2} \text { for }\right. \\
\text { control group). The mean reduction in ulcer } \\
\text { area was significantly more in the PBM group } \\
\text { than in the control group }\left(322.44 \pm 85.84 \mathrm{~mm}^{2}\right. \\
\text { and } 1043.20 \pm 266.62 \mathrm{~mm}{ }^{2}, \text { respectively). } \\
\text { Ulcers treated with PBM showed a significant } \\
\text { reduction in percentage wound area ( } 40.24 \pm \\
\left.6.30 \mathrm{~mm}^{2}\right) \text { compared to } 11.87 \pm 4.28 \mathrm{~mm} 2 \text { in } \\
\text { control groups }\end{array}$ & [74] \\
\hline 660 & 2 & $(100 \mathrm{~mW})$ & - & $\begin{array}{l}\text { Irradiated } \\
\text { daily for } 12 \\
\text { consecutive } \\
\text { days. }\end{array}$ & $\begin{array}{l}\text { Diabetic patients } \\
\text { presenting with presenting } \\
\text { grade II, III, or IV. }\end{array}$ & $\begin{array}{l}\text { Digital photography and } \\
\text { removal of granulation } \\
\text { tissue for gene analysis } \\
\text { (RT-qPCR)-IL-6, TNF- } \alpha \text {, } \\
\text { VEGF, and TGF- } \beta \text {. }\end{array}$ & $\begin{array}{l}\text { PBM produced a reduction in wound size } \\
\text { accompanied by an improvement of the } \\
\text { biochemical markers: VEGF and TGF- } \beta \\
\text { expression increased, and TNF- } \alpha \text { expression } \\
\text { decreased post-PBM. Wound size improved } \\
\text { by around } 50 \% \text { after } 7 \text { days, and exhibited } \\
\text { increased cellular activity at the wound edge } \\
\text { and base, and faster formation of } \\
\text { granulation tissue. }\end{array}$ & [75] \\
\hline
\end{tabular}

* Actual dose differed from incident dose due to losses due to the acrylic glass cage and reflection of light energy by the rat's skin. The actual doses were calculated and can be found in the original manuscript [49]. bFGF, basic fibroblast growth factor; CFU, colony forming units; EGF, epidermal growth factor; FBS, fetal bovine serum; FGF, fibroblast growth factor; IL-6, interleukin-6; IL-1 $\beta$, interleukin 1 beta; LED, light emitting diode; MMP, matrix metalloproteinase; NO, nitric oxide; NF- $\mathrm{BB}$, nuclear factor kappa-light-chain-enhancer of activated B p-STAT5, phosphorylated signal transducer and activator of transcription 5; PDGF, platelet-derived growth factor; PMNL, polymorphonuclear leukocyte; ROS, reactive oxygen species; STZ, streptozotocin; TBARS, thiobarbituric acid reactive substances; TIMP, tissue inhibitor of metalloproteinases; TGF- $\beta$, transforming growth factor beta; TNF- $\alpha$, tumor necrosis factor alpha; VEGF, vascular endothelial growth factor. 


\section{Conclusions}

Wound repair is an attempt of the biological system to restore tissue integrity and denotes the outcome of numerous sequential, time-based, interconnected biological events that are highly coordinated in response to injury and its microenvironment. The colossal economic and social impact of chronic wounds on modern day society calls for a higher level of consideration and improved treatments. PBM has shown promising results in vitro, as well as in animal and human studies. The effects are reported to be anti-inflammatory; stimulate cell proliferation, viability, and migration; promote essential cytokine and growth factor production and release; foster collagen and ECM production; decrease inhibitory MMPs; and decrease oxidative stress, all vital processes to promote healing of chronic wounds and diabetic ulcers. Blue light has also been shown to be effective against the killing and inhibition of pathogens, including MRSA, providing promise for this therapy to be used in the treatment of infected wounds. Noninvasive, economical, and versatile light devices are an appealing tool for wound management, either in combination with standard care or alone, especially considering all of the cellular effects of PBM. This review provided a background for applications of PBM for wound healing under conditions of hyperglycemia. The shortage of rigorous, well-designed clinical trials makes it challenging to assess the scientific impact of PBM on DFUs, and lack of understanding of the underlying mechanisms also hinders the conventional use of this therapy. There is a crucial need for the wound care community to develop optimal clinical protocols for use based on well-designed studies, and for basic research to determine the underlying cellular and molecular effects, and mechanisms of action. Further research that makes use of the correct study design and laser parameters is required, and more studies on infected wounds are essential.

Funding: This research was funded by the South African Research Chairs Initiative of the Department of Science and Technology and National Research Foundation of South Africa (Grant No 98337), as well as grants received from the University of Johannesburg (URC), the National Research Foundation (NRF), and the Council for Scientific and Industrial Research (CSIR)-National Laser Centre (NLC) Laser Rental Pool Program.

Conflicts of Interest: The author declares no conflict of interest. The funders had no role in the writing of the manuscript, or in the decision to publish.

\section{References}

1. International Diabetes Federation (2017) IDF Diabetes Atlas. Eighth Edition. Available online: https: //diabetesatlas.org/resources/2017-atlas.html (accessed on 23 September 2019).

2. Allen, R.J., Jr.; Soares, M.A.; Haberman, I.D.; Szpalski, C.; Schachar, J.; Lin, C.D.; Nguyen, P.D.; Saadeh, P.B.; Warren, S.M. Combination Therapy Accelerates Diabetic Wound Closure. PLoS ONE 2014, 9, e92667. [CrossRef] [PubMed]

3. Miyajima, S.; Shirai, A.; Yamamoto, S.; Okada, N.; Matsushita, T. Risk factors for major limb amputations in diabetic foot gangrene patients. Diabetes Res. Clin. Pract. 2006, 71, 272-279. [CrossRef] [PubMed]

4. Hogan, P.; Dall, T.; Nikolov, P. Economic costs of diabetes in the US in 2002. Diabetes Care 2003, 26, 917-932. [PubMed]

5. Sen, C.K.; Gordillo, G.M.; Roy, S.; Kirsner, R.; Lambert, L. Human skin wounds: A major and snowballing threat to public health and the economy. Wound Rep. Reg. 2009, 17, 763-771. [CrossRef] [PubMed]

6. Anders, J.J.; Arany, P.R.; Baxter, G.D.; Lanzafame, R.J. Light-Emitting Diode Therapy and Low-Level Light Therapy Are Photobiomodulation Therapy. Photobiomodul. Photomed. Laser Surg. 2019, 37, 63-65. [CrossRef] [PubMed]

7. Lavery, L.A.; Hunt, N.A.; LaFontaine, J.; Baxter, C.L.; Ndip, A.; Boulton, A.J.M. Diabetic foot prevention: A neglected opportunity in high-risk patients. Diabetes Care 2010, 33, 1460-1462. [CrossRef]

8. Peter-Riesch, B. The diabetic foot: The never-ending challenge. Endocr. Dev. 2016, 31, 108-134. [CrossRef]

9. Weledji, E.P.; Fokam, P. Treatment of the diabetic foot-To amputate or not? BMC Surg. 2014, 14, 83. [CrossRef]

10. Tsourdi, E.; Barthel, A.; Rietzsch, H.; Reichel, A.; Bornstein, S.R. Current Aspects in the Pathophysiology and Treatment of Chronic Wounds in Diabetes Mellitus. BioMed. Res. Int. 2013. [CrossRef]

11. Hunt, T.K. Basic principles of wound healing. J. Trauma 1990, 30, S122-S128. [CrossRef] 
12. Mester, E.; Szende, B.; Tota, J.G. Effect of laser on hair growth of mice. Kiserl Orvostud. 1967, 19, 628-631.

13. Mester, E.; Spiry, T.; Szende, B.; Tota, J.G. Effect of laser rays on wound healing. Am. J. Surg. 1971, 122, 532-535. [CrossRef]

14. Mester, E.; Szende, B.; Spiry, T.; Scher, A. Stimulation of wound healing by laser rays. Acta Chir. Acad. Sci. Hung. 1972, 13, 315-324. [PubMed]

15. Mester, E.; Nagylucskay, S.; Doklen, A.; Tisza, S. Laser stimulation of wound healing. Acta Chir. Acad. Sci. Hung. 1976, 17, 49-55.

16. Chung, H.; Dai, T.; Sharma, S.K.; Huang, Y.-Y.; Carroll, J.D.; Hamblin, M.R. The Nuts and Bolts of Low-level Laser (Light) Therapy. Ann. Biomed. Eng. 2012, 40, 516-533. [CrossRef]

17. Greco, M.; Guida, G.; Perlino, E.; Marra, E.; Quagliariello, E. Increase in RNA and protein synthesis by mitochondria irradiated with helium-neon lase. Biochem. Biophys. Res. Commun. 1989, 163, 1428-1434. [CrossRef]

18. Gao, X.; Xing, D. Molecular mechanisms of cell proliferation induced by low power laser irradiation. J. Biomed. Sci. 2009, 16, 4. [CrossRef]

19. Houreld, N.N.; Masha, R.T.; Abrahamse, H. Low-intensity laser irradiation at $660 \mathrm{~nm}$ stimulates cytochrome c oxidase in stressed fibroblast cells. Lasers Surg. Med. 2012, 44, 429-434. [CrossRef]

20. Karu, T.I. Multiple roles of cytochrome c oxidase in mammalian cells under action of red and IR-A radiation. IUBMB Life 2010, 62, 607-610. [CrossRef]

21. Karu, T.I.; Pyatibrat, L.V.; Kolyakov, S.F.; Afanasyeva, N.I. Absorption measurements of cell monolayers relevant to mechanisms of laser phototherapy: Reduction or oxidation of cytochrome c oxidase under laser irradiation at $632.8 \mathrm{~nm}$. Photomed. Laser Surg. 2008, 26, 593-599. [CrossRef]

22. Yu, W.; Naim, J.O.; McGowan, M.; Ippolito, K.; Lanzafame, R.J. Photomodulation of oxidative metabolism and electron chain enzymes in rat liver mitochondria. Photochem. Photobiol. 1997, 66, 866-871. [CrossRef] [PubMed]

23. Masha, R.T.; Houreld, N.N.; Abrahamse, H. Low-intensity laser irradiation at $660 \mathrm{~nm}$ stimulates transcription of genes involved in the electron transport chain. Photomed. Laser. Surg. 2013, 31, 47-53. [CrossRef] [PubMed]

24. Silveira, P.C.L.; da Silva, L.A.; Fraga, D.B.; Freitas, T.P.; Streck, E.L.; Pinhoa, R. Evaluation of mitochondrial respiratory chain activity in muscle healing by low-level laser therapy. J. Photochem. Photobiol. B 2009, 95, 89-92. [CrossRef] [PubMed]

25. Passarella, S.; Casamassima, E.; Molinari, S.; Pastore, D.; Quagliariello, E.; Catalano, I.M.; Cingolani, A. Increase of proton electrochemical potential and ATP synthesis in rat liver mitochondria irradiated in vitro by helium-neon laser. FEBS Lett. 1984, 175, 95-99. [CrossRef]

26. Silveira, P.C.; Silva, L.A.; Pinho, C.A.; Souza, P.S.; Ronsani, M.M.; Scheffer, D.L.; Pinho, R.A. Effects of low-level laser therapy (GaAs) in an animal model of muscular damage induced by trauma. Lasers Med. Sci. 2013, 28, 431-436. [CrossRef] [PubMed]

27. Chen, A.C.-H.; Arany, P.R.; Huang, Y.-Y.; Tomkinson, E.M.; Sharma, S.K.; Kharkwal, G.B.; Saleem, T.; Mooney, D.; Yull, F.E.; Blackwell, T.S.; et al. Low-level laser therapy activates NF-kB via generation of reactive oxygen species in mouse embryonic fibroblasts. PLoS ONE 2011, 6, e22453. [CrossRef]

28. Zungu, I.L.; Hawkins-Evans, D.; Abrahamse, H. Mitochondrial responses of normal and injured human skin fibroblasts following low level laser irradiation-An in vitro study. Photochem. Photobiol. 2009, 85, 987-996. [CrossRef]

29. Pyo, S.-J.; Song, W.-W.; Kim, I.-R.; Park, B.-S.; Kim, C.-H.; Shin, S.-H.; Chung, I.-K.; Kim, Y.-D. Low-level laser therapy induces the expression of BMP-2, osteocalcin, and TGF- $\beta 1$ in hypoxic-cultured human osteoblasts. Lasers Med. Sci. 2013, 28, 543-550. [CrossRef]

30. Zhang, R.; Mio, Y.; Pratt, P.F.; Lohr, N.; Warltier, D.C.; Whelan, H.T.; Zhu, D.; Jacobs, E.R.; Medhora, M.; Bienengraeber, M. Near infrared light protects cardiomyocytes from hypoxia and reoxygenation injury by a nitric oxide dependent mechanism. J. Mol. Cell. Cardiol. 2009, 46, 4-14. [CrossRef]

31. Huang, Y.-Y.; Chen, A.C.-H.; Carroll, J.D.; Hamblin, M.R. Biphasic dose response in low level light therapy. Dose-Response 2009, 7, 358-383. [CrossRef]

32. Ferraresi, C.; Hamblin, M.R.; Parizotto, N.A. Low-level laser (light) therapy (LLLT) on muscle tissue: Performance, fatigue and repair benefited by the power of light. Photon. Lasers Med. 2012, 1, 267-286. [CrossRef] [PubMed]

33. Lane, N. Cell biology: Power games. Nature 2006, 443, 901-903. [CrossRef] [PubMed] 
34. Lohr, N.L.; Keszler, A.; Pratt, P.; Bienengraber, M.; Warltier, D.C.; Hogg, N. Enhancement of nitric oxide release from nitrosyl hemoglobin and nitrosyl myoglobin by red/near infrared radiation: Potential role in cardioprotection. J. Mol. Cell. Cardiol. 2009, 47, 256-263. [CrossRef] [PubMed]

35. Houreld, N.N.; Sekhejane, P.R.; Abrahamse, H. Irradiation at 830nm Stimulates Nitric Oxide Production and Inhibits Pro-Inflammatory Cytokines in Diabetic Wounded Fibroblast Cells. Lasers Surg. Med. 2010, 42, 494-502. [CrossRef]

36. Pal, G.; Dutta, A.; Mitra, K.; Grace, M.S.; Amat, A.; Romanczyk, T.B.; Wu, X.; Chakrabarti, K.; Anders, J.; Gorman, E.; et al. Effect of low intensity laser interaction with human skin fibroblast cells using fiber-optic nano-probes. J. Photochem. Photobiol. B 2007, 86, 252-261. [CrossRef]

37. Lipovsky, A.; Nitzan, Y.; Gedanken, A.; Lubart, R. Visible Light-Induced Killing of Bacteria as a Function of Wavelength: Implication for Wound Healing. Lasers Surg. Med. 2010, 42, 467-472. [CrossRef]

38. Biener, G.; Masson-Meyers, D.S.; Bumah, V.V.; Hussey, G.; Stoneman, M.R.; Enwemeka, C.S.; Raicu, V. Blue/violet laser inactivates methicillin-resistant Staphylococcus aureus by altering its transmembrane potential. J. Photochem. Photobiol. B 2017, 170, 118-124. [CrossRef]

39. Amaroli, A.; Ravera, S.; Baldini, F.; Benedicenti, S.; Panfoli, I.; Vergani, L. Photobiomodulation with 808-nm diode laser light promotes wound healing of human endothelial cells through increased reactive oxygen species production stimulating mitochondrial oxidative phosphorylation. Lasers Med. Sci. 2019, 34, 495-504. [CrossRef]

40. Assis, L.; Moretti, A.I.S.; Abrahão, T.B.; Cury, V.; Souza, H.P.; Hamblin, M.R.; Parizotto, N.A. Low-Level Laser Therapy $(808 \mathrm{~nm}$ ) Reduces Inflammatory Response and Oxidative Stress in Rat Tibialis Anterior Muscle after Cryolesion. Lasers Surg. Med. 2012, 44, 726-735. [CrossRef]

41. Otterço, A.N.; Andrade, A.L.; Brassolatti, P.; Pinto, K.N.Z.; Araújo, H.S.S.; Parizotto, N.A. Photobiomodulation mechanisms in the kinetics of the wound healing process in rats. J. Photochem. Photobiol. B 2018, 183, $22-29$. [CrossRef]

42. Damante, C.A.; De Micheli, G.; Miyagi, S.P.H.; Feist, I.S.; Marques, M.M. Effect of laser phototherapy on the release of fibroblast growth factors by human gingival fibroblasts. Lasers Med. Sci. 2009, 24, 885-891. [CrossRef] [PubMed]

43. Jere, S.W.; Houreld, N.N.; Abrahamse, H. Photobiomodulation at $660 \mathrm{~nm}$ stimulates proliferation and migration of diabetic wounded cells via the expression of epidermal growth factor and the JAK/STAT pathway. J. Photochem. Photobiol. B 2018, 179, 74-83. [CrossRef] [PubMed]

44. Fiorio, F.B.; Dos Santos, S.A.; de Melo Rambo, C.S.; Dalbosco, C.G.; Serra, A.J.; de Melo, B.L.; Leal-Junior, E.C.P.; de Carvalho, P.T.C. Photobiomodulation therapy action in wound repair skin induced in aged rats old: Time course of biomarkers inflammatory and repair. Lasers Med. Sci. 2017, 32, 1769-1782. [CrossRef] [PubMed]

45. Enwemeka, C.S.; Williams, D.; Enwemeka, S.K.; Hollosi, S.; Yens, D. Blue 470-nm Light Kills Methicillin-Resistant Staphylococcus aureus (MRSA) in Vitro. Photomed. Laser Surg. 2009, 27, 221-226. [CrossRef] [PubMed]

46. Bumah, V.V.; Aboualizadeh, E.; Masson-Meyers, D.S.; Eells, J.T.; Enwemeka, C.S.; Hirschmug, C.J. Spectrally resolved infrared microscopy and chemometric tools to reveal the interaction between blue light $(470 \mathrm{~nm})$ and methicillin-resistant Staphylococcus aureus. J. Photochem. Photobiol. B 2017, 167, 150-157. [CrossRef]

47. Masson-Meyers, D.S.; Bumah, V.V.; Enwemeka, C.S. A comparison of fourmethods for determining viability in human dermal fibroblasts irradiated with blue light. J. Pharmacol. Toxicol. Methods 2016, 79, 15-22. [CrossRef]

48. Opländer, C.; Hidding, S.; Werners, F.B.; Born, M.; Pallua, N.; Suschek, C.V. Effects of blue light irradiation on human dermal fibroblasts. J. Photochem. Photobiol. B 2011, 103, 118-125. [CrossRef]

49. Al-Watban, F.A.H. Laser Therapy Converts Diabetic Wound Healing to Normal Healing. Photomed. Laser Surg. 2009, 27, 127-135. [CrossRef]

50. Eissa, M.; Salih, W.H.M. The influence of low-intensity He-Ne laser on the wound healing in diabetic rats. Lasers Med. Sci. 2017, 32, 1261-1267. [CrossRef]

51. Jere, S.W.; Houreld, N.N.; Abrahamse, H. Role of the PI3K/AKT (mTOR and GSK3 $\beta$ ) signalling pathway and photobiomodulation in diabetic wound healing. Cytokine Growth Factor Rev. 2019. [CrossRef] 
52. Esmaeelinejad, M.; Bayat, M. Effect of low-level laser therapy on the release of interleukin- 6 and basic fibroblast growth factor from cultured human skin fibroblasts in normal and high glucose mediums. J. Cosmet. Laser Ther. 2013, 15, 310-317. [CrossRef] [PubMed]

53. Khoo, N.K.; Shokrgozar, M.A.; Kashani, I.R.; Amanzadeh, A.; Mostafavi, E.; Sanati, H.; Habibi, L.; Talebi, S.; Abouzaripour, M.; Akrami, S.M. In vitro therapeutic effects of low level laser at mRNA level on the release of skin growth factors from fibroblasts in diabetic mice. Avicenna J. Med. Biotechnol. 2014, 6, 113-118. [PubMed]

54. Ma, H.; Li, Y.; Chen, H.; Kang, M.; Cheng-Yi Liu, T. Effects of low-intensity laser irradiation on wound healing in diabetic rats. Int. J. Photoenergy 2012, 2012. [CrossRef]

55. Bitar, M.S. The GSK-3 $\beta / \mathrm{Fyn} / \mathrm{Nrf2}$ pathway in fibroblasts and wounds of type 2 diabetes: On the road to an evidence-based therapy of non-healing wounds. Adipocyte 2012, 1, 161-163. [CrossRef]

56. Akyol, U.; Güngörmüş, M. The Effect of Low-Level Laser Therapy on Healing of Skin Incisions Made Using a Diode Laser in Diabetic Rats. Photomed. Laser Surg. 2018, 28, 51-55. [CrossRef]

57. Sekhejane, P.R.; Houreld, N.N.; Abrahamse, H. Irradiation at 636nm Positively Affects Diabetic Wounded and Hypoxic Cells in Vitro. Photomed. Laser Surg. 2011, 29, 521-530. [CrossRef]

58. Kunkemoeller, B.; Kyriakides, T.R. Redox Signaling in Diabetic Wound Healing Regulates Extracellular Matrix Deposition. Antioxid. Redox Signal. 2017, 27, 823-838. [CrossRef]

59. Carvalho, P.D.T.C.D.; Silva, I.S.D.; Reis, F.A.D.; Perreira, D.M.; Aydos, R.D. Influence of InGaAls laser (660nm) on the healing of skin wounds in diabetic rats. Acta. Cir. Bras. 2010, 25, 71-79. [CrossRef]

60. Tatmatsu-Rocha, J.C.; Ferraresi, C.; Hamblin, M.R.; Damasceno Maia, F.; do Nascimento, N.R.; Driusso, P.; Parizotto, N.A. Low-level laser therapy $(904 \mathrm{~nm})$ can increase collagen and reduce oxidative and nitrosative stress in diabetic wounded mouse skin. J. Photochem. Photobiol. B 2016, 164, 96-102. [CrossRef]

61. Peplow, P.V.; Chung, T.Y.; Ryan, B.; Baxter, G.D. Laser photobiostimulation of wound healing: Reciprocity of irradiance and exposure time on energy density for splinted wounds in diabetic mice. Lasers Surg. Med. 2011, 43, 843-850. [CrossRef]

62. Lau, P.; Bidin, N.; Krishnan, G.; AnaybBaleg, S.M.; Sum, M.B.M.; Bakhtiar, H.; Nassir, Z.; Hamid, A. Photobiostimulation effect on diabetic wound at different power density of near infrared laser. J. Photochem. Photobiol. B 2015, 151, 201-207. [CrossRef]

63. Aparecida Da Silva, A.; Leal-Junior, E.C.P.; Alves, A.C.A.; Rambo, C.S.; Dos Santos, S.A.; Vieira, R.P.; De Carvalho, P.D.T.C. Wound-healing effects of low-level laser therapy in diabetic rats involve the modulation of MMP-2 and MMP-9 and the redistribution of collagen types I and III. J. Cosmet. Laser Ther. 2013, 15, 210-216. [CrossRef]

64. Ayuk, S.M.; Houreld, N.N.; Abrahamse, H. Collagen production in diabetic wounded fibroblasts in response to low-intensity laser irradiation at $660 \mathrm{~nm}$. Diabetes Technol. Ther. 2012, 14, 1110-1117. [CrossRef] [PubMed]

65. Ayuk, S.M.; Houreld, N.N.; Abrahamse, H. Laser irradiation alters the expression profile of genes involved in the extracellular matrix in vitro. Int. J. Photoenergy 2014, 2014. [CrossRef]

66. Ayuk, S.M.; Abrahamse, H.; Houreld, N.N. The role of photobiomodulation on gene expression of cell adhesion molecules in diabetic wounded fibroblasts in vitro. J. Photochem. Photobiol. B 2016, 161, 368-374. [CrossRef]

67. Ranjbar, R.; Takhtfooladi, M.A. The effects of photobiomodulation therapy on Staphylococcus aureus infected surgical wounds in diabetic rats. A microbiological, histopathological, and biomechanical study. Acta. Cir. Bras. 2016, 31, 498-504. [CrossRef]

68. Chung, T.-Y.; Peplow, P.V.; Baxter, G.D. Testing Photobiomodulatory Effects of Laser Irradiation on Wound Healing: Development of an Improved Model for Dressing Wounds in Mice. Photomed. Laser Surg. 2010, 28, 589-596. [CrossRef]

69. Pay, A.D.; Kenealy, J.M. Laser transmission through membranes using the Q-switched Nd:YAG laser. Lasers Surg. Med. 1999, 24, 48-54. [CrossRef]

70. Chen, C.; Diven, D.G.; Lockhart, S.; Bell, B. Laser transmission through membranes used in cutaneous laser treatment. J. Am. Acad. Dermatol. 2001, 45, 919-923. [CrossRef] [PubMed]

71. Nteleki, B.; Abrahamse, H.; Houreld, N. Conventional podiatric intervention and phototherapy in the treatment of diabetic ulcers. Semin. Vasc. Surg. 2015, 28, 172-183. [CrossRef]

72. Mathur, R.K.; Sahu, K.; Saraf, S.; Patheja, P.; Khan, F.; Gupta, P.K. Low-level laser therapy as an adjunct to conventional therapy in the treatment of diabetic foot ulcers. Lasers Med. Sci. 2017, 32, 275-282. [CrossRef] [PubMed] 
73. Kaviani, A.; Djavid, G.E.; Ataie-Fashtami, L.; Fateh, M.; Ghodsi, M.; Salami, M.; Zand, N.; Kashef, N.; Larijani, B. Randomized clinical trial on the effect of low-level laser therapy on chronic diabetic foot wound healing: A preliminary report. Photomed. Laser Surg. 2011, 29, 109-114. [CrossRef] [PubMed]

74. Kajagar, B.M.; Goghi, A.S.; Pandit, A.; Khatri, S. Efficacy of low level laser therapy on wound healing in patients with chronic diabetic foot ulcers-A randomized control trial. Indian J. Surg. 2012, 74, 359-363. [CrossRef] [PubMed]

75. Ruh, A.C.; Frigo, L.; Cavalcanti, M.F.X.B.; Svidnicki, P.; Vicari, V.N.; Lopes-Martins, R.A.B.; Leal Junior, E.C.P.; De Isla, N.; Diomede, F.; Trubiani, O.; et al. Laser photobiomodulation in pressure ulcer healing of human diabetic patients: Gene expression analysis of inflammatory biochemical markers. Lasers Med. Sci. 2018, 33, 165-171. [CrossRef] [PubMed]

(C) 2019 by the author. Licensee MDPI, Basel, Switzerland. This article is an open access article distributed under the terms and conditions of the Creative Commons Attribution (CC BY) license (http://creativecommons.org/licenses/by/4.0/). 